\title{
LETTERS
}

\section{Dare we hope}

In an era when cries of "Lock her up" can rile a crowd to frenzy, it is the duty of a responsible editor to ensure that declamatory comment is backed up by academic rigour. It is clear that CMAJ recently failed this test. ${ }^{1}$ It has compounded the error by encouraging the media to fan the flames such that the associated front page article of The Star claims that the journal is calling for an end to celebrating Sir William Osler. ${ }^{2}$ Neither the authors nor the editor acknowledged the debt that CMAJ has to Osler, who not only encouraged its foundation but also frequently contributed articles when he was world-renowned and the journal was not.

The article is based on a non sequitur. Why did the editors not correct the intended, but false, impression that Drs. Augusta, Abbott, Oronhyatekha and Jones are forgotten because we are obsessed with Osler? Osler never hindered the careers of these physicians. Indeed, I believe that he would have supported the current interest in them, just as societies named for Osler have supported research into each of their lives. All of these doctors are included in the Dictionary of Canadian Biography, easily available online. Drs. Augusta and Abbott feature in a book to be published by the American College of Surgeons on the historical role of Black surgeons in American medicine. Dr. Michelle
Hamilton presented her biography of Dr. Oronhyatekha, published by Dundurn Press a few years ago, to Western University's Osler Society. ${ }^{3}$

The authors also used hearsay to condemn Osler. Death from pneumonia was more common among Black patients, just as with coronavirus disease 19 today. Why did the authors not quote from Osler when he addressed the topic of race directly?

"By his commission the physician is sent to the sick, and knowing in his calling neither Jew nor Gentile, bond or free, perhaps he alone rises superior to those differences which separate and make us dwell apart, too often oblivious to the common hopes and common frailties which should bind us together."4

"... the priestly character of the physician has vanished with the ages; still there is left with us a strong feeling, of brotherhood, a sense of unity, which the limitations of language, race and country have not been able to efface." 4

"Distinctions of race, nationality, colour, and creed are unknown within the portals of the temple of Aesculapius. Dare we dream that this harmony and cohesion so rapidly developing in medicine, obliterating the strongest lines of division, knowing no tie of loyalty, but loyalty to truth dare we hope, I say, that in the wider range of human affairs a similar solidarity may ultimately be reached?"5

If we have not achieved what Osler dared to hope for a century ago, we should look to ourselves before we sling mud at another.

\section{Vivian McAlister MB}

Surgeon, University of Western Ontario, London, Ont.

- Cite as: CMAJ 2021 January 18;193:

E103. doi: 10.1503/cmaj.77457

\section{References}

1. Persaud N, Butts H, Berger P. William Osler: saint in a "White man's dominion". CMAJ 2020;192: E1414-6.

2. Oved M. Sir William Osler, the father of modern medicine, made openly racist statements - and it's time to stop celebrating him, medical journal article says. The Star [Toronto]. Available: www. thestar.com/news/investigations/2020/11/09/ sir-william-osler-the-father-of-modern-medicine -made-openly-racist-statements-and-its-time-to -stop-celebrating-him-medical-journal-article-says. html (accessed 2020 Nov. 9).

3. Hamilton M, Jamieson K. Dr. Oronhyatekha: security, justice, and equality. Toronto: Dundurn Press; 2017.

4. Osler W. Rudolph Virchow, the man and the student. Boston Med Surg J 1891;125:425-7.

5. Osler W. Aequanimitas, with other addresses to medical students, nurses and practitioners of medicine. Philadelphia: P. Blakiston's Son \& Co; 1905:188.

Competing interests: None declared.

Content licence: This is an Open Access article distributed in accordance with the terms of the Creative Commons Attribution (CC BY-NC-ND 4.0) license, which permits use, distribution and reproduction in any medium, provided that the original publication is properly cited, the use is non-commercial (i.e. research or educational use), and no modifications or adaptations are made. See: https://creativecommons.org/licenses/ by-nc-nd/4.0/ 